\title{
Forum
}

\section{Rotational Grazing Systems and Livestock Grazing Behavior in Shrub-Dominated Semi-Arid and Arid Rangelands}

\author{
Derek W. Bailey ${ }^{1}$ and Joel R. Brown ${ }^{2}$ \\ Authors are ${ }^{1}$ Professor, Department of Animal and Range Sciences, New Mexico State University, Las Cruces, NM 88003, USA; and ${ }^{2}$ Rangeland \\ Specialist, US Department of Agriculture-Natural Resources Conservation Service, Jornada Experimental Range, New Mexico State University, \\ Las Cruces, NM 88003, USA.
}

\begin{abstract}
Rotational grazing systems (RGS) are often implemented to alleviate undesirable selective grazing by livestock. At both fine and coarse scales, livestock selectively graze individual plants, patches, communities, and landscapes. Smaller pastures, increased stocking density, and rotation allow managers to constrain livestock movement and determine season and frequency of grazing, potentially limiting selectivity and preventing repeated grazing of preferred plants. However, in arid and semi-arid rangelands, forage growth is limited primarily by precipitation rather than defoliation frequency. When soil moisture is adequate, forage is abundant and defoliation levels are typically low, and repeated, intensive defoliation of preferred plants is less likely than in more mesic areas where more consistent precipitation and soil moisture storage allows animals to establish and maintain spatial hierarchies of grazing patterns. Many southwestern rangelands contain diverse vegetation, which provides quality forage during different times of the year. These spatial and temporal patterns of forage distribution may not be amenable to manipulation with RGS. Tracking data show that livestock often alternate among locations within pasture boundaries and can opportunistically exploit areas with higher quality forage when they are available. Higher stock densities combined with higher stocking rates can increase livestock use of less preferred areas, but overall distribution patterns of intensive-rotational and extensive grazing systems are often comparable at similar stocking rates and distances from water. Management that ensures that grazing of riparian areas does not occur during the critical late summer period may be more beneficial than RGS that periodically defers livestock use throughout the grazing season. In arid and semi-arid shrublands, timely adjustments to animal numbers and practices that improve grazing distribution at regional and landscape scales are more likely to be effective in maintaining or improving rangeland health than fencing and RGS.
\end{abstract}

\section{Resumen}

Los sistemas de pastoreo rotativos (SPR) son utilizados frecuentemente para contrarrestar los efectos no-deseados del pastoreo selectivo del ganado. Tanto a escalas finas como gruesas el ganado pastorea selectivamente plantas individuales, parches, comunidades y paisajes. Potreros más pequeños, mayor densidad animal, y la rotación permiten poner límites al movimiento de los animales y determinar la estación y la frecuencia de pastoreo, limitando potencialmente la selectividad y previniendo el pastoreo reiterado de plantas preferidas. Sin embargo, en pastizales áridos y semiáridos, el crecimiento del forraje está limitado principalmente por precipitación y no por la frecuencia de defoliación. Cuando la humedad edáfica es adecuada, el forraje es abundante y los niveles de defoliación son típicamente bajos, y la defoliación repetida e intensa de plantas preferidas es menos probable que en áreas más mésicas donde la precipitación consistente y el almacenaje del agua en el suelo permiten que los animales establezcan y mantengan jerarquías espaciales de patrones de pastoreo. Muchos de los pastizales naturales del sudoeste de los Estados Unidos contienen vegetación diversa que provee forraje de calidad en distintos momentos del año. Estos patrones espaciales y temporales de distribución de forraje podrían no ser susceptibles a ser manipulados a través de SPR. Datos de monitoreo con GPS demuestran que los vacunos alternan entre lugares dentro de los limites de un potrero y que pueden utilizar áreas de mayor calidad de forraje de modo oportunista cuando las mismas están disponibles. Densidades animales más elevadas combinadas con cargas animales más altas podrían incrementar el uso de áreas menos preferidas pero los patrones globales de distribución del pastoreo de sistemas rotativos intensivos y sistemas de pastoreo extensivos son frecuentemente comparables bajo condiciones similares de carga animal y distancia al agua. Un manejo que asegure la exclusión del pastoreo de aéreas ribereñas (vegas/mallines/humedales) en el período crítico de fines del verano podría ser más beneficial que SPR que periódicamente difieren el uso del ganado durante la estación de pastoreo. En estepas arbustivas áridas y semiáridas ajustes oportunos del número de animales y prácticas que mejoren la distribución del pastoreo a escalas regionales y del paisaje podrían ser más efectivos que la construcción de alambrados y el uso de SPR en mantener o mejorar la salud del pastizal.

Key Words: foraging strategies, grazing management, grazing systems, livestock behavior, livestock distribution, stocking density

Correspondence: Derek W. Bailey, Animal and Range Sciences, New Mexico State University,

PO Box 30003, MSC 3-I, Las Cruces, NM 88003, USA. Email: dwbailey@nmsu.edu

Manuscript received 3 December 2009; manuscript accepted 18 September 2010.

\section{INTRODUCTION}

Free ranging livestock and other large herbivores are highly selective during foraging and demonstrate their preferences at 
both fine and coarse spatial and temporal scales (Senft et al. 1987). Rangeland managers have been concerned over the years that the cumulative effects of repeated selective defoliation will contribute to the loss of more palatable species and a corresponding increase of less palatable species (Heady 1961; Mueggler 1972). To alleviate selective grazing across multiple scales, many rangeland managers have implemented rotational grazing systems (RGS). Rotating livestock among pastures has been advocated on rangelands for over $100 \mathrm{yr}$ (Smith 1895). For the purpose of this article, RGS refers to grazing systems such as those described by Savory (1983 and 1988) and Savory and Parsons (1980) where relatively small paddocks with high stock densities are grazed for short periods. However, much of the discussion could apply to other grazing systems where livestock are concentrated and moved periodically to achieve higher stock densities and limited grazing periods (Briske et al. 2008). The potential benefits are projected to derive from a decrease in area available to livestock at any given time (improved distribution); an increase in stock density (increased uniformity of defoliation across species and communities); and periodic deferment (to allow regrowth). Although these potential benefits hold much promise for the enhanced management of rangelands, results of experimental trials have been less than positive (Briske et al. 2008). Much of the research comparing RGS to continuous grazing has not shown measurably increased plant or livestock production in arid and semi-arid rangelands (Briske et al. 2008). While the effect of fences in controlling livestock movements is obvious, the effect of concentrating livestock on defoliation patterns and regrowth is quite variable. Increasing plant productivity by defoliation (herbivore optimization), although supported by some observations, remains questionable as a universal management principle (Bartolome 1993). Likewise, achieving uniform defoliation is difficult, given the array of physical and chemical properties represented within most rangeland plant communities (Brown and Stuth 1993). Our focus in this article will be to examine the relevant literature to evaluate the impact of RGS on livestock selectivity of forages (diet selection) and feeding sites (grazing distribution) compared to continuous or seasonlong grazing systems in shrub-dominated arid $(<250 \mathrm{~mm}$ annual precipitation) and semi-arid $(250-500 \mathrm{~mm}$ annual precipitation) rangelands. Other critical issues germane to the comparison of RGS to continuous grazing, such as forage regrowth and vegetative responses, while critical to performance, will not be discussed here. Instead, our first objective will be to identify how implementation of RGS may potentially affect animal selectivity at fine and coarse spatial and temporal scales compared to continuous systems. Our second objective is to describe how common misconceptions regarding livestock grazing behavior have contributed to expectations for RGS.

\section{Is Livestock Selectivity a Problem?}

Livestock and other large herbivores must make decisions regarding foraging at fine and coarse spatial scales (Senft et al. 1987). At fine scales, animals select the plant or plant parts to consume given their placement of their front feet (feeding station). At intermediate scales, livestock select patches and feeding stations within patches. At coarser scales, livestock select feeding sites and in some cases camps (Bailey et al. 1996). At all scales, livestock select forages that have greater concentrations of nutrients and fewer toxins. Although forage quality is usually much more important than forage quantity, animals must select plants with sufficient biomass to maintain bite size and total daily forage intake. At coarser scales, topography and water availability can constrain where livestock choose to graze and affect selection of feeding sites and camps (Bailey et al. 1996). Typically, livestock avoid steep slopes and areas that are far horizontally and vertically from water (Valentine 1947; Mueggler 1965; Roath and Krueger 1982).

As a consequence of selectivity, livestock grazing patterns are often uneven with some areas of landscapes and pastures receiving little use and others sometimes receiving moderate or heavy use (Senft et al. 1985; Bailey 2005; DelCurto et al. 2005). At finer scales, more palatable plant species are usually grazed more heavily than less palatable plant species (Provenza 1995, 1996). Preferential grazing of more palatable plants may give a competitive advantage to nearby plants that are not grazed (Mueggler 1972; Archer and Detling 1984). One of the reasons often cited for implementing RGS is to provide periodic deferment or rest during the growing season for grasses that are selectively grazed (Briske et al. 2008). Overcoming multiscale heterogeneity induced by animal selectivity is a major factor that has motivated rangeland scientists and managers to develop and implement grazing systems of many kinds. Managers typically view the RGS objective of increased homogeneity of defoliation patterns (Savory 1983, 1988) as a method to alleviate adverse impacts that may occur in response to selective grazing.

Although often considered as a problem to be overcome by rangeland managers, animal selectivity may also have beneficial aspects. Selectivity allows livestock to obtain a high quality diet (Heady 1964; Allison 1985; Senft 1989). Animals must be selective in order to avoid toxins and secondary compounds (Molyneaux and Ralphs 1992; Provenza 1996; Launchbaugh et al. 2001). Selective grazing allows heterogeneous structure to emerge. For example, stocking rangeland at light rates in relatively mesic areas with forage regrowth during the grazing period often results in patch grazing (Ring et al. 1985). This patch-grazing increases variation in vertical structure and can be beneficial for wildlife (Vavra 2005; Derner et al. 2009).

A central tenant of grazing management is proper distribution. Typically, rangeland managers, advisors, and researchers have regarded this to mean uniform distribution. An often stated objective of RGS has been uniform defoliation of individual plants, species, communities, and landscapes (Savory 1983, 1988). In addition to being difficult to achieve, uniform defoliation may be of less value to conservation and production values than commonly assumed (Kerby et al. 2007; Derner et al. 2009).

In addition to composition of herbaceous species, density of shrubs plays a critical role in the diversity of arid and semi-arid shrublands. When density of shrubs is relatively low, shrubs increase heterogeneity. In contrast, shrubs homogenize landscapes and plant communities when densities are high. Riparian areas in arid and semi-arid shrublands provide essential wildlife habitat and contribute greatly to the overall diversity of these systems. Such heterogeneity can be beneficial to biodiversity, wildlife, and even livestock (Fuhlendorf and Engle 2004). 


\section{Do Rotational Grazing Systems Alter Livestock Selectivity? Do High Stocking Densities Reduce Selectivity?}

Subdivision of pastures is the most common method used in RGS to increase stocking density, although there have been other labor-intensive approaches such as herding. Increasing stocking density has been proposed as a technique to increase the uniformity of grazing and decrease selectivity within a management unit (Savory 1988). In practice, increases in stocking density (animal unit/land unit) are often confused with or confounded with increases in stocking rate (animal unit/land unit/time unit) or grazing pressure index (animal unit/available forage; Scarnecchia and Kothmann 1982). Researchers and practitioners must carefully segregate the impacts of stocking density and stocking rate when evaluating the effects of RGS on animal selectivity, behavior, and performance. In a wide range of climatic conditions, researchers have found that grazing distribution of livestock was not affected by changes in stocking density if stocking rate was held constant. BurboaCabrera et al. (2003) evaluated the impacts of stocking densities varying from 9 to 54 steers $\cdot \mathrm{ha}^{-1}$ at the same stocking rate in a 2-yr study conducted in Nebraska. They found that selectivity of forage species by livestock was not affected by stocking density, and spatial distribution of grazing as measured by utilization uniformity indices was similar among four diverse stocking densities. Walker et al. (1989) reported that selectivity of cattle for plant communities in Texas was either not affected by an increase in stocking density from 0.17 to 12.5 animal units $\cdot \mathrm{ha}^{-1}$ or was slightly increased by the highest stocking density in the RGS. Kirby et al. (1986) found that grazing distribution was not affected by implementation of a RGS compared to season-long continuous grazing in western North Dakota despite a $1400 \%$ increase in stocking density with the RGS. Barnes et al. (2008) found that uniformity of forage utilization within a RGS was not affected by a fourfold increase in stocking density when stocking rates were similar.

At extremely high stocking densities, grazing may become more uniform. Volesky (1994) found that at stocking densities of 80 to 170 steers $\cdot$ ha $^{-1} 98 \%$ of tillers were defoliated. However, stocking densities of this magnitude (frontal grazing) would not be practical in arid and semi-arid shrublands where forage production is much lower than in the central Oklahoma study of Volesky (1994). Two studies conducted in central Kansas (Smith and Owensby 1978; Ring et al. 1985) reported that increases in stocking density reduced patch grazing. In these studies, early intensive stocking was more effective in preventing patch grazing than season-long grazing. Early intensive stocking allows managers to end grazing when forage begins to mature and does not force managers to carry sufficient dormant forage for livestock to graze during periods of little or no growth. The requirement to retain dormant forage in RGS to maintain livestock during periods of little or no growth may help explain why animal performance was not improved through RGS (Briske et al. 2008).

Subdivision of larger pastures into smaller paddocks facilitates increased stocking density, but it does not offset the effects of increased stocking rates. Livestock become less selective at higher stocking rates or grazing pressure indices. Hart et al. (1993a) concluded that stocking rates have more potential to alter frequency and intensity of defoliation and thereby selectivity of livestock than grazing systems. At higher stocking levels, livestock are forced to consume less palatable forages and travel farther from water and use rougher terrain to maintain intake. However, the decrease in animal selectivity comes at a cost. Livestock performance declines as stocking rates or grazing pressure index increases (Hart et al. 1988; Hart and Ashby 1998) and ecological risk increases (Taylor et al. 1997; Holechek et al. 1999; Reece et al. 2001).

\section{Limit Potential of Livestock to Regraze Forage}

One of the reasons that pastures are subdivided and RGS are implemented is to give managers the ability to control timing and frequency of grazing. The confinement of livestock in one pasture of the grazing system theoretically prevents animals from continually regrazing the same plants (Holechek et al. 2001). However, in arid and semi-arid rangelands, periods of active forage growth are relatively limited. Precipitation is limited and unpredictable, and the times that soil moisture is readily available and temperatures are favorable are normally limited. As a result, plants grow and mature in arid and semiarid shrublands over relatively short periods and with little opportunity for regrowth after grazing. In periods of favorable precipitation when regrowth could readily occur, total forage production and forage quality are usually both sufficiently high that livestock would not require regrowth of grazed plants to maintain intake. Comparing defoliation patterns from a site in eastern Oklahoma with $830 \mathrm{~mm}$ of annual precipitation (Derner et al. 1994) to a site in southern Wyoming with $338 \mathrm{~mm}$ of annual precipitation (Hart et al. 1993b) illustrates this point. In Oklahoma, Derner et al. (1994) observed that fewer plants remained ungrazed with a RGS compared to continuous grazing, but Hart et al. (1993b) found little difference in defoliation patterns between RGS and continuous grazing.

In contrast to uplands, riparian areas in shrub-dominated arid and semi-arid rangelands have sufficient soil moisture to allow for forage regrowth while temperatures are favorable (growing season). Early in the summer, cattle preference for riparian areas is similar to uplands, while later in the summer cattle highly prefer riparian areas (Marlow and Pogacnik 1986; Parsons et al. 2003). Higher temperatures in late summer and corresponding attraction to water and shade may help explain the attraction of riparian areas to livestock late in the summer seasons. In addition, forage quality of upland grasses may drop later in the summer as the plants mature and while quality of riparian forage may remain relatively favorable (Kauffman et al. 1983; DelCurto et al. 2005). Chronic intensive grazing is likely to occur if animals are allowed to remain season-long in pastures with riparian areas. Grazing during the late summer season is also more likely to result in use of riparian woody species (Kauffman et al. 1983). Periodic movement of livestock from one pasture to the next could potentially limit chronic intense use of riparian areas to pastures grazed in late summer. Movement of cattle to a new pasture when stubble heights reach a given height (e.g., $10 \mathrm{~cm}$ ) may also help maintain species composition and channel morphology of riparian areas (Clary and Leininger 2000). However, implementation of a RGS does not assure that areas with riparian zones will not be grazed periodically in late summer, nor does it automatically assure stubble heights will remain above recommended levels. 

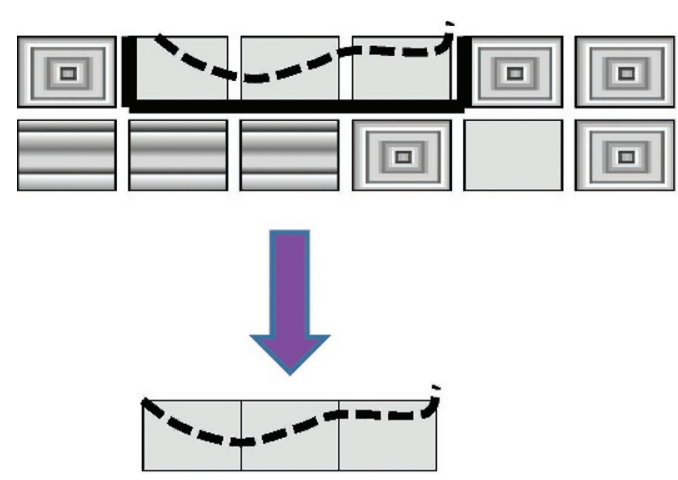

Fencing similar

areas together can improve distribution

\section{Feeding sites}

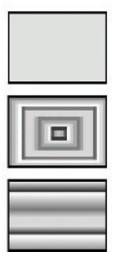

Preferred

Intermediate

Avoided
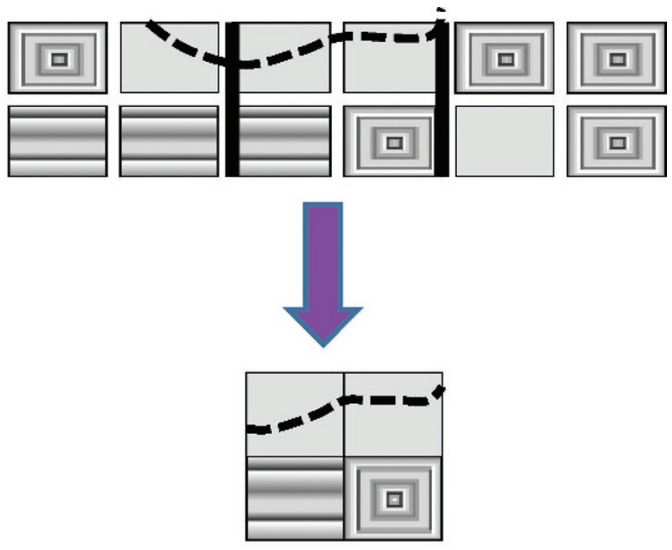

Fencing dissimilar areas together may have little affect on distribution

Figure 1. Example of the potential for strategic fence placement to affect livestock grazing distribution. Preferred feeding sites (solid squares) would commonly be riparian areas or areas of high forage quality next to water and be the location of the majority of grazing (Bailey 2005). Intermediate feeding sites (outlined squares) are also grazed by livestock but are not as preferred (e.g., uplands with gentle slopes). Avoided sites (striped squares) would include high and steep terrain with intermediate forage quality. Two examples of subdivision of the pasture are presented. If a new pasture encloses only one type of feeding site (such as preferred sites), livestock are more likely to graze uniformly. An example of such a strategy is riparian pastures. However, simply reducing pasture size will not necessarily improve uniformity of grazing, especially if dissimilar feeding sites are enclosed.

\section{Increase Uniformity of Feeding Areas}

Fence construction associated with implementation of RGS can be used to improve livestock grazing distribution if fences are strategically placed. Bailey (1995) found that yearling cattle grazing alternated among homogeneous feeding sites, but selected feeding sites with higher quality forage and avoided a feeding site with lower forage quality in Oklahoma. In a crested wheatgrass (Agropyron cristatum [L.] Gaertn.) seeding in Colorado, Bailey et al. (1990) found that cows were not observed in the same area of the pasture for more than two consecutive days. Cattle appeared to rotate among feeding sites in this relatively homogenous pasture. Bailey and Provenza (2008) also reported that cattle in Montana alternated among feeding sites in a relatively homogeneous pasture, but remained in some sites and avoided others in a heterogeneous pasture.

If a large heterogeneous pasture is to be subdivided into multiple paddocks, placement of the fences can dramatically change grazing distribution. The key to improving livestock distribution through strategic placement of fencing is to enclose homogeneous areas (Bailey and Rittenhouse 1989; Bailey 2005). In Figure 1, a mountainous pasture with a riparian area is subdivided into three equally sized paddocks without regard to the plant communities and terrain. The result is smaller heterogeneous pastures. A simple reduction in pasture size in this case would have minimal effects in livestock distribution. In contrast, if similar areas are enclosed, the paddock would become more homogeneous and grazing distribution would likely be more uniform within each of the paddocks. When pastures are subdivided into smaller paddocks without the consideration of ecological sites, plant communities, or terrain and diverse feeding areas are enclosed together with minimal, if any, improvement in grazing distribution, the effects of spatial heterogeneity can be exacerbated.

\section{MISCONCEPTIONS REGARDING LIVESTOCK GRAZING BEHAVIOR}

\section{Livestock Select Diets in Strict Deference to Palatability}

RGS are often implemented to provide periodic deferment of grazing because managers believe that cattle have overgrazed the most palatable plants. They are concerned that the lack of defoliation on less palatable plants and heavy defoliation of the most palatable plants would put the most palatable plants at a 
competitive disadvantage (Mueggler 1972). Provenza et al. (2003) have stated that they have trained livestock to "eat the best and leave the rest" through the use of low stock densities, which has led to a decline in biodiversity and an increase in less desirable forages. An alternative possibility is that high stocking densities only collapse the processes of defoliation that occur at lower densities into a shorter period of time. For example, plants that would be defoliated during the first few days of a grazing period at low stock densities would likely be grazed during the first few hours at high stock densities. Correspondingly, plants defoliated during the last few days of a grazing period at low stock densities would be defoliated during the last day at higher stocking densities. Irving et al. (1995) observed the temporal patterns of defoliation by cattle in long narrow pastures $(0.4 \times 3.2 \mathrm{~km})$ in Alberta. Cattle grazed areas within $1.6 \mathrm{~km}$ to water on the first $2 \mathrm{~d}$ and areas between $1.6 \mathrm{~km}$ and $3.2 \mathrm{~km}$ from water during the last $3 \mathrm{~d}$ of the 5-d grazing periods. Selection of areas close to water was not overcome by high stocking densities, but it was masked by the rapid rates of defoliation progressing in a "wave-like" pattern from water to the end of the pasture. The pattern of defoliation appeared uniform at the end of grazing, but it was actually the culmination of a wave of selective grazing that ended when the cattle were removed.

Quality of forages during the growing season is continuously changing as plants grow and mature. With cool and warm season species, annuals, and perennials, the list of more palatable plants is rarely constant. Variable timing of precipitation and changes in temperature may change which plants are the most palatable. Cruz and Ganskopp (1998) found that some plants that were the most preferred in the vegetative state were the least preferred at quiescence. Similarly, Gesshe and Walton (1981) found that some plants that were preferred in the vegetative state were strongly avoided during the seed set stage, but they also found that plants were avoided during the vegetative stage and highly preferred at seed set. Rather than a constant list, the most preferred plants are a dynamic collection that readily changes both temporally and spatially across most rangelands. When phenological stages of forages become mixed, livestock may become less selective and focus on availability of higher quality forages irrespective of species composition (Stuth 1991). However, phenology may not be an adequate predictor of selectivity. Brown and Stuth (1993) compared defoliation intensity of two dominant warm-season grasses in a mesic grassland grazed at different stocking rates in a rotational system. Little bluestem (Schizachyrim scoparium [Michx.] Nash) tillers were preferentially selected by cattle compared to brownseed paspalum (Paspalum plicatulum Michx.) regardless of season, stocking rate, or phenological stage. The level of grazing pressure necessary to overcome the selectivity was not exceeded in any grazing period in their study, although levels were limiting for animal intake and performance.

Selection is often a tradeoff between availability and quality (Ganskopp et al. 1997; Cruz and Ganskopp 1998). As more palatable plants are defoliated, livestock are more likely to switch to less palatable plants (Heady 1964; Cruz and Ganskopp 1998). Livestock are keenly sensitive to the availability of forages and will alter diet selection accordingly (Edwards et al. 1996). As a result, the most preferred plants may not be selected as frequently as the sward becomes defoliated. Bartolome (1993) argued that most of the vegetative changes on rangelands attributed to selective grazing by livestock can be better explained by differences in grazing intensity and stocking rates.

\section{Livestock Graze in the Same Areas}

Managers frequently also implement RGS in an attempt to overcome landscape scale livestock grazing distribution patterns. They assume that most cattle and other free-roaming livestock graze in only a few areas, typically near water (Holechek 1988), and periodic livestock movements as part of a RGS ensure that chronic over grazing is avoided. However, livestock rotate themselves through large pastures in continuous grazing systems. Cattle rarely spend more than $2 \mathrm{~d}$ in the same area of homogeneous pastures (Bailey et al. 1990; Bailey 1995). In mountainous and heterogeneous pastures, cattle may revisit some areas for several days in a row, but they do visit other areas (Bailey and Provenza 2008). In juniper-grassland savannahs in central New Mexico, yearling heifers rotated themselves throughout 259-ha pastures $(n=4)$ even though stocking rates were light (19 ha $\cdot$ animal unit month ${ }^{-1}$; D. W. Bailey, unpublished data, 2005). Pastures were divided into four 55-ha areas excluding locations within $300 \mathrm{~m}$ of water. Heifers were tracked with global positioning system (GPS) collars for $53 \mathrm{~d}$ during autumn. Heifers were within the same 55 -ha area of a pasture during consecutive mornings on $24.5 \pm 1.9 \%$ of the days tracked, which is within levels expected by chance. During the other roughly three-fourths of the study, heifers grazed different portions of the pastures on consecutive mornings, which resulted in relatively uniform forage utilization patterns. Adapted cattle are usually willing to travel long distances from water and use steep and high terrain. Bailey et al. (2004) found that cows grazing within the pasture could have very different grazing patterns with some animals using high and steep terrain (hill climbers), while others used gentle terrain near water. Hill-climbing cows continued to use rugged terrain more uniformly than bottom-dwelling cows even after they were separated (Bailey et al. 2006). Differences in grazing patterns were clearly apparent, with hill climbers spending more time on higher terrain than bottom dwellers during the grazing periods (Fig. 2). Adapted cattle are willing to travel long distances from water even though stocking densities are low and forage is available near water. In the Chihuahuan Desert of New Mexico (Bailey et al. 2010), native Brangus cattle traveled over $3.7 \mathrm{~km}$ from water and grazed within an area of 535 ha, while naïve Brangus cattle traveled less than $3.0 \mathrm{~km}$ from water and grazed within a 369-ha area. After averaging all recorded locations together, native cattle were $1.6 \mathrm{~km}$ from water, while naïve cattle were $0.8 \mathrm{~km}$. From this GPS tracking data, it is clear that adapted livestock can travel long distances from water and do not remain in one area near water even when pastures are large and stocking densities are relatively low.

\section{HOW SHOULD WE MANAGE TO ALLEVIATE IMPACTS OF SELECTIVE GRAZING?}

In arid and semi-arid rangelands (both shrub dominated and grass dominated), light to moderate stocking rates are more 


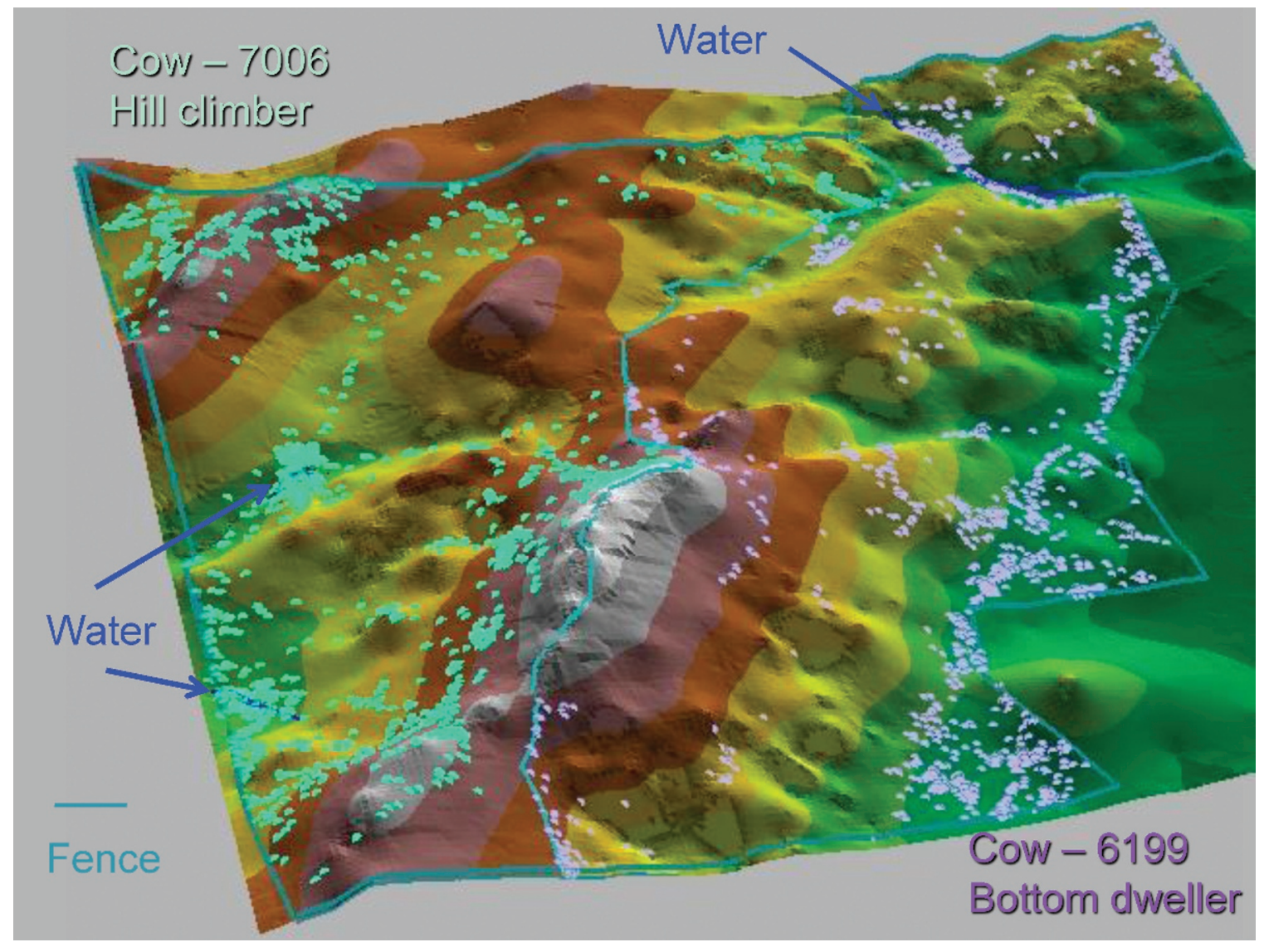

Figure 2. Locations of two cows grazing adjacent mountainous pastures in northern Montana during August. Positions were recorded with global positioning system collars every 10 min for 2 wk. Cow 7006 in the left pasture was identified as a hill climber during previous observations (Bailey et al. 2006), while cow 6199 in the right pasture was identified as a bottom dweller. This is an example of the potential differences in grazing among cows. Approximately 100 other cows were in each pasture along with the tracked cows.

sustainable than heavier levels (Holechek et al. 1999, 2003). At lighter stocking rates, there is less ecological risk than at heavier rates (Reece et al. 2001) and managers have more options to address a variety of concerns, including selective grazing.

Livestock make decisions of which plant or plant part to graze every $1 \mathrm{~s}$ to $2 \mathrm{~s}$ during active grazing bouts (Senft et al. 1987; Bailey et al. 1996). As a result, it is much more difficult to manipulate which plants livestock will graze (Bailey 2005). However, we can manage which parts of pastures livestock graze. Excessive utilization of localized areas can usually be resolved by increasing the time livestock spend in areas that typically receive little use (Bailey 2004). Grazing distribution practices have been recommended for over $50 \mathrm{yr}$ (Williams 1954), but the recent development of GPS technology has allowed researchers to document the effectiveness of these practices. Water developments can dramatically alter grazing distribution, especially if pastures contain areas that are horizontally or vertically far from water. Salt and other mineral supplements have only a limited potential to lure cattle away from water (Ganskopp 2001; Bailey and Welling 2007), and are most effective when the forage is lush, has a high moisture content, and is relatively uniform in palatability. Low moisture block protein supplements are a much more powerful cattle attractant than salt during the fall (Bailey et al. 2008b).

Changing the season of grazing can be a powerful tool for increasing uniformity of grazing in mountainous rangeland
(DelCurto et al. 2005). Herding can also be used to manipulate cattle grazing patterns. Bailey et al. (2008a) successfully decreased cattle use of riparian areas by moving animals from areas near streams to the sagebrush-dominated uplands.

Riparian areas in arid and semirangeland usually respond very favorably if grazing is excluded or if grazing is deferred during critical periods. Wyman et al. (2006) described multiple approaches for improving livestock grazing management of riparian areas. Most methods involve either deferment of grazing during critical periods (e.g., late summer), or management of grazing intensity (e.g., herding). Riparian areas provide water, shade, and high quality forage during the growing season (DelCurto et al. 2005) and as a result are often one of the biggest challenges in management of grazing distribution and livestock selectivity.

Movement of livestock among paddocks is an integral part of RGS. Movement from one pasture to another at appropriate times or deferment of grazing at critical periods are useful tools for managing livestock grazing in semi-arid rangelands containing riparian areas. Correspondingly, many land managers and rangeland scientists assume that RGS should be the best method for managing rangelands with riparian areas. However, in an extensive review of upland rangelands, Briske et al. (2008) found that pasture rotation and periodic deferment did not improve animal performance or improve vegetative productivity on arid and semi-arid rangelands. In a recent 
review of livestock grazing management and riparian areas, George et al. (2010) found a limited number of studies evaluating grazing system effects on riparian areas and those evaluated did not provide any evidence that RGS were beneficial for improving or maintaining riparian area condition. Pasture rotation, higher stocking densities, and reduced duration of grazing within a pasture associated with RGS do not necessarily provide the management shown to help maintain and improve riparian area condition and function. With RGS, livestock still graze riparian areas during critical periods and livestock can still congregate along streambanks.

For targeted grazing, high stocking densities combined with heavy stocking rates are often employed to ensure livestock consume specified plants within constrained areas to control noxious weeds, improve wildlife habitat, reduce fuel loads, and achieve other management objectives (Launchbaugh et al. 2006). Targeting grazing with high stocking densities and grazing pressure indices can be very effective, and animals can be forced to consume or trample plants that are less palatable (Derner et al. 2009). However, use of more palatable plants can be heavy before less palatable plants are grazed. Correspondingly, animal intake, diet quality, and performance are typically compromised with targeted grazing (Launchbaugh et al. 2006), and the risk of poisoning from toxic plants also increases (Merrill and Schuster 1978). However, since the goal of targeted grazing is vegetation management, decreases in animal performance are often acceptable to management.

\section{MANAGEMENT IMPLICATIONS}

We have argued that RGS often have little, if any, impact on animal selectivity, yet RGS continue to be recommended as a tool to overcome the undesirable consequences of selectivity. Increasing stocking density through RGS only increases the rate at which pasture forage is defoliated. In most cases, it does not change the underlying livestock selection patterns. In contrast, developing water reduces the distance livestock must travel to water in nearby portions of the pasture. Consequently, grazing distribution should become more uniform. Although changes in stocking density at a given stocking rate have little effect on livestock selectivity, diet selection and grazing distribution can be modified and in many cases made more uniform by increasing stocking rate. However, this comes at the cost of lower animal performance and potentially negative impacts on vegetative condition and channel stability of riparian areas.

Periodic movement of livestock between pastures to minimize intensity of grazing near streambanks and to defer grazing during critical periods may benefit riparian systems. However, implementation of RGS may not be the solution to improve riparian health even though livestock movement and periodic pasture deferment are a component of RGS. Development of specific grazing management practices for specific riparian systems is more likely to be beneficial than application of a RGS or other generalized grazing system. Rather than focusing on how to prevent selectivity or ameliorate the effects of selectivity through RGS, perhaps it is time to reallocate our efforts to managing selectivity when needed and feasible (e.g., grazing distribution practices) and prospering from the improved performance of livestock when they are selective.

\section{ACKNOWLEDGMENTS}

This article was part of the International Symposium entitled "Livestock management in shrub-dominated semi-arid rangelands: a comparison of landscape histories and pattern use in the Mediterranean and South-western North America" held at the 61st Society for Range Management Annual Meeting in Louisville, Kentucky. Funding for this symposium was provided by Dow Agrosciences.

\section{LITERATURE CITED}

Alusson, C. D. 1985. Factors affecting forage intake by range ruminants: a review. Journal of Range Management 38:305-311.

Archer, S., and J. K. Detulng. 1984. The effects of defoliation and competition on regrowth of tillers of two North American mixed-grass prairie graminoids. Oikos 43:351-357.

Balley, D. W. 1995. Daily selection of feeding areas by cattle in homogeneous and heterogeneous environments. Applied Animal Behaviour Science 45:183199.

BAlLEY, D. W. 2004. Management strategies for optimal grazing distribution and use of arid rangelands. Journal Animal Science 82(E. Suppl):E147-E153.

Balley, D. W. 2005. Identification and creation of optimal habitat conditions for livestock. Rangeland Ecology \& Management 58:109-118.

Bailey, D. W., J. E. Gross, E. A. Laca, L. R. Rittenhouse, M. B. Coughenour, D. M. Swift, And P. L. Sims. 1996. Mechanisms that result in large herbivore grazing distribution patterns. Journal of Range Management 49:386-400.

Bailey, D. W., M. R. KeIL, And L. R. Rittenhouse. 2004. Research observation: daily movement patterns of hill climbing and bottom dwelling cows. Journal of Range Management 57:20-28.

Balley, D. W., And F. D. Provenza. 2008. Mechanisms determining large-herbivore distribution. In: H. H. T. Prins and F. van Langevelde [EDS.]. Resource ecology: spatial and temporal dynamics of foraging. Dordrecht, Netherlands: Springer. p. 7-28.

Balley, D. W., and L. R. Rittenhouse. 1989. Management of cattle distribution. Rangelands 11:159-161.

Balley, D. W., M. G. Thomas, J. W. Walker, B. K. Witmore, and D. Tolleson. 2010. Effect of previous experience on grazing patterns and diet selection of Brangus cows in the Chihuahuan Desert. Rangeland Ecology and Management 63:223-232.

Balley, D. W., H. C. VanWagoner, and R. Weinmeister. 2006. Individual animal selection has the potential to improve uniformity of grazing on foothill rangeland. Rangeland Ecology \& Management 59:351-358.

Balley, D. W., H. C. VanWagoner, R. Weinmeister, and D. Jenson. 2008a. Evaluation of low-stress herding and supplement placement for managing cattle grazing in riparian and upland areas. Rangeland Ecology \& Management 61:26-37.

Balley, D. W., H. C. VanWagoner, R. Weinmeister, and D. Jenson. 2008b. Comparison of low-moisture blocks and salt for manipulating grazing patterns of beef cows. Journal of Animal Science 86:1271-1277.

Balley, D. W., J. W. Walker, and L. R. Rittenhouse. 1990. Sequential analysis of cattle location: day-to-day movement patterns. Applied Animal Behaviour Science 25:137-148.

Balley, D. W., and G. R. Weluing. 2007. Evaluation of low-moisture blocks and conventional dry mixes for supplementing minerals and modifying cattle grazing patterns. Rangeland Ecology \& Management 60:54-64.

Barnes, M. K., B. E. Norton, M. Maeno, and J. C. Malechek. 2008. Paddock size and stocking density affect spatial heterogeneity of grazing. Rangeland Ecology \& Management 61:380-388.

Bartolome, J. W. 1993. Application of herbivore optimization theory to rangelands of the western United States. Ecological Applications 3:27-29.

Briske, D. D., J. D. Derner, J. R. Brown, S. D. Fuhlendorf, W. R. Teague, K. M. Havstad, R. L. Gillen, A. J. Ash, And W. D. Wilms. 2008. Rotational grazing on rangelands: reconciliation of perception and experimental evidence. Rangeland Ecology \& Management 61:3-17. 
Brown, J. R., AND J. W. Stuth. 1993. How herbivory affects grazing tolerant and sensitive grasses in a central Texas grassland: integrating plant response across hierarchical levels. Oikos 67:291-297.

Burboa-Cabrera, F. R., W. H. Schacht, and B. E. Anderson. 2003. Utilization and grazing distribution of cattle at 4 stocking densities. Journal of Range Management 56:328-333.

Clary, W. P., and W. C. Leininger. 2000. Stubble height as a tool for management of riparian areas. Journal of Range Management 53:562-573.

Cruz, R., And D. Ganskopp. 1998. Seasonal preferences of steers for prominent northern Great Basin grasses. Journal of Range Management 51:557-565.

DelCurto, T., M. Porath, C. T. Parsons, and J. A. Morrison. 2005. Management strategies for sustainable beef cattle grazing on forested rangelands in the Pacific Northwest. Rangeland Ecology \& Management 58:119-127.

Derner, J. D., R. L. Gillen, F. T. McCollum, and K. W. Tate. 1994. Little bluestem tiller defoliation patterns under continuous and rotational grazing. Journal of Range Management 47:220-225.

Derner, J. D., W. K. Lauenroth, P. Stapp, and D. J. Augustine. 2009. Livestock as ecosystem engineers for grassland bird habitat in the western Great Plains of North America. Rangeland Ecology \& Management 62:111-118.

Edwards, G. R., J. A. Newman, A. J. Parsons, and J. R. Krebs. 1996. Effects of the total, vertical and horizontal availability of the food resource on diet selection and intake of sheep. Journal of Agriculture Sciences 127:555-562.

FuHLendorf, S. D., AND D. M. Engle. 2004. Restoring heterogeneity on rangelands: ecosystem management based on evolutionary grazing patterns. Bioscience $51: 625-632$

GansKOPP, D. 2001. Manipulating cattle distribution with salt and water in large arid-land pastures: a GPS/GIS assessment. Applied Animal Behaviour Science 73:251-262.

Ganskopp, D., B. Myers, S. Lambert, and R. Cruz. 1997. Preferences and behavior of cattle grazing 8 varieties of grasses. Journal of Range Management 50:578588.

George, M. R., R. D. Jackson, C. S. Boyd, and K. W. Tate. 2011. A scientific assessment of the effectiveness of riparian management practices. In: D. Briske [ED.]. Assessment of the effectiveness of conservation practices applied to rangelands. Lawrence, KS, USA: Allen Press, Inc. In press.

Gesshe, R. H., and P. D. Walton. 1981. Grazing animal preferences for cultivated forages in Canada. Journal of Range Management 34:42-45.

HaRT, R. H., AND M. H. AshBy. 1998. Grazing intensities, vegetation, and heifer gains: 55 years on shortgrass. Journal of Range Management 51:392-398.

Hart, R. H., J. Bisso, M. J. Samuel, and J. W. Waggoner. 1993a. Grazing systems, pasture size, and cattle grazing behavior, distribution and gains. Journal of Range Management 46:81-87.

HaRT, R. H., S. Clapp, And P. S. TeSt. 1993b. Grazing strategies, stocking rates, and frequency and intensity of grazing on western wheatgrass and blue grama. Journal of Range Management 46:122-126.

Hart, R. H., M. J. Samuel, P. S. Test, and M. A. Simth. 1988. Cattle, vegetation and economic responses to grazing systems and grazing pressure. Journal of Range Management 41:282-286.

HeAdY, H. F. 1961. Continuous vs. specialized grazing systems: a review and application to the California annual type. Journal of Range Management 14:182-193.

HEADY, H. F. 1964. Palatability of herbage and animal preference. Journal of Range Management 17:76-82

HolecheK, J. L. 1988. An approach for setting the stocking rate. Rangelands 10:10-14

Holechek, J. L., D. Galt, J. Joseph, J. Navarro, G. Khumalo, F. Molinar, and M. Thomas. 2003. Moderate and light cattle grazing effects on Chihuahuan Desert rangelands. Journal of Range Management 56:133-139.

HolecheK, J. L., R. D. PIeper, And C. H. Herbel. 2001. Range management principles and practices. 4th ed. Upper Saddle River, NJ, USA: Prentice Hall. 587 p.

Holechek, J. L., M. G. Thomas, F. Molinar, and D. Galt. 1999. Stocking desert rangelands: what have we learned? Rangelands 21(6):8-12.

Irving, B. D., P. L. Rutledge, A. W. Balley, M. A. Naeth, and D. S. Chanasyk. 1995 Grass utilization and grazing distribution within intensively managed fields in Central Alberta. Journal of Range Management 48:358-361.
Kauffman, J. B., W. C. Krueger, and M. Vavra. 1983. Effects of late season cattle grazing on riparian plant-communities. Journal of Range Management 36:685-691.

Kerby, J. D., S. D. Fuhlendorf, and D. M. Engle. 2007. Landscape heterogeneity and fire behavior: scale-dependent feedback between fire and grazing processes. Landscape Ecology 22:507-516.

KirBy, D. R., M. F. Pessin, and G. K. Clambey. 1986. Disappearance of forage under short-duration and season-long grazing. Journal of Range Management 39:496-500

Launchbaugh, K. L., R. J. Daines, and J. W. Walker [eds.]. 2006. Targeted grazing: a natural approach to vegetation management and landscape enhancement. Centennial, CO, USA: American Sheep Industry Association. 199 p. Available at: http://www.cnr.uidaho.edu/rx-grazing/Handbook.htm. Accessed 17 November 2009.

Launchbaugh, K. L., F. D. Provenza, and J. A. Pfister. 2001. Herbivore response to anti-quality factors in forages. Journal of Range Management 54:431-440.

Marlow, C. B., and T. M. Pogacnik. 1986. Cattle feeding and resting patterns in a foothills riparian zone. Journal of Range Management 39:212-217.

MerRiLL, L. B., AND J. L. Schuster. 1978. Grazing management practices affect livestock losses from poisonous plants. Journal of Range Management 31:351-354.

Molyneaux, R. J., and M. H. Ralphs. 1992. Plant toxins and palatability of herbivores. Journal of Range Management 45:13-18.

MueggleR, W. F. 1965. Cattle distribution on steep slopes. Journal of Range Management 18:255-257.

Mueggler, W. F. 1972. Influence of competition on the response of bluebunch wheatgrass to clipping. Journal of Range Management 25:88-92.

Parsons, C. T., P. A. Momont, T. DelCurto, M. Mclnnis, and M. L. Porath. 2003. Cattle distribution patterns and vegetation use in mountain riparian areas. Journal of Range Management 56:334-341.

Provenza, F. D. 1995. Postingestive feedback as an elementary determinant of food preference and intake in ruminants. Journal of Range Management 48:2-17

ProvenzA, F. D. 1996. Acquired aversions as the basis for varied diets of ruminants foraging on rangelands. Journal of Animal Science 74:2010-2020.

Provenza, F. D., J. J. Villalba, L. E. Dziba, S. B. Atwood, and R. E. Banner. 2003. Linking herbivore experience, varied diets, and plant biochemical diversity. Small Ruminant Research 49:257-274.

Reece, P. E., J. D. Volesky, and W. H. Schacht. 2001. Integrating management objectives and grazing strategies on semi-arid rangeland. Lincoln, NE, USA: University Nebraska-Lincoln Extension. EC01-158. 20 p.

Ring, C. B., R. A. Nicholson, and J. L. Launchbaugh. 1985. Vegetation traits of patchgrazed rangeland in west-central Kansas. Journal of Range Management 38:51-55.

Roath, L. R., and W. C. Krueger. 1982. Cattle grazing and behavior on a forested range. Journal of Range Management 35:332-338.

SAVORY, A. 1983. The Savory grazing method or holistic resource management. Rangelands 5:155-159.

Savory, A. 1988. Holistic resource management. Covelo, CA, USA: Island Press. $564 \mathrm{p}$

Savory, A., and S. Parsons. 1980. The Savory grazing method. Rangelands 2:234-237.

Scarnecchia, D. L., and M. M. Kothmann. 1982. A dynamic approach to grazing management terminology. Journal of Range Management 35:262-264.

SENFT, R. L. 1989. Hierarchical foraging models: effects of stocking and landscape composition on simulated resource use by cattle. Ecological Modelling 46:283-303.

Senft, R. L., M. B. Coughenour, D. W. Balley, L. R. Rittenhouse, O. E. Sala, and D. M. SwIFT. 1987. Large herbivore foraging and ecological hierarchies. BioScience 37:789-799

Senft, R. L., L. R. Rittenhouse, and D. R. G. Woodmansee. 1985. Factors influencing patterns of cattle grazing behavior on shortgrass steppe. Journal of Range Management 38:82-87.

Smith, E. F., and C. E. OwensBy. 1978. Intensive-early stocking and season-long stocking of Kansas flint hill range. Journal of Range Management 31:14-17. 
SMITH, J. G. 1895. Forage conditions of the prairie region. In: USDA Yearbook of Agriculture-1895. Washington, DC, USA: US Department of Agriculture. p. 309-324.

Stuth, J. W. 1991. Foraging behavior. In: R. K. Heitschmidt and J. Stuth [eds.]. Grazing management: an ecological perspective. Portland, OR, USA: Timber Press, Inc. p. 65-83.

Taylor, C. A., M. H. Ralphs, and M. M. Kothmann. 1997. Technical note: vegetation response to increasing stocking rate under rotational stocking. Journal of Range Management 50:439-442.

Valentine, K. A. 1947. Distance from water as a factor in grazing capacity of rangeland. Journal of Forestry 45:749-754.

VavRA, M. 2005. Livestock grazing and wildlife: developing compatibilities. Rangeland Ecology \& Management 58:128-135.
VoleskY, J. D. 1994. Tiller defoliation patterns under frontal, continuous and rotational grazing. Journal of Range Management 47:215-219.

Walker, J. W., R. K. Heitschmidt, and S. L. Dowhower. 1989. Some effects of a rotational grazing treatment on cattle preference for plant communities. Journal of Range Management 42:143-148.

WiLliams, R. E. 1954. Modern methods of getting uniform use of ranges. Journal of Range Management 7:77-81.

Wyman, S., D. W. Balley, M. Borman, S. Cote, J. Eisner, B. Leinard, S. Leonard, F. Reed, S. Swanson, L. Van Riper, T. Westfall, R. Wiley, and A. Winward. 2006. Riparian area management: grazing management processes and strategies for riparian-wetland areas. Denver, CO, USA: US Department of Interior, Bureau of Land Management, National Science and Technology Center. Technical Reference TR 1737-20. BLM/ST/ST-06/002+1737. 105 p. 